\title{
41 細管型自動粘度測定装置の開発
}

斉藤浩一, 戸川達男 (東京医科歯科大医器材研 - 計測機器部門) 勝崎宣夫 (ヤヨイ)

最近の粘度計は回転式をはじめ, 測定の自動化ぶ進 められている。しかしながら試料の入れ替兄, 装置の 洗浄などは構造上，手作業に頼らざるを得ない，そこ で我々は試料のサンプリングから粘度の測定および洗 浄までを自動で行觉る細管型の粘度計の閒発を行った ので報告する.

装置はオートサンプラー, 温度制御器, 真空ポンプ, 流速計測器などから構成される。細管は内径約 $1 \mathrm{~mm}$ のテフロンチューブを用いた．粘度測定に必要な試料 は $0.5 \mathrm{ml}$ で, オートサンプラーのターンテーブル上 には20種までの試料をセットできる、サンプリングさ れた試料は陰圧で引かれ，細管内を移動する．細管は 途中, 電子冷熱式の温度制御プレート上を通り，15〜 $45^{\circ} \mathrm{C}$ までの任意の設定温度に保たれる. 温度の設定 精度は $\pm 0.05^{\circ} \mathrm{C}$ とした. 温度制御された試料は細管 上に取り付けた 2 つのフォトディテクタ間を通過する. この時の通過時間から流速を計算し, 較正液での流速 と比較して粘度が算出される。市た粘度測定後は自動
的に洗浄液を吸引し，細管内のクリーニングを行う. 測定は洗浄時問を含めても約 3 分で終了する. 粘度の 測定範囲は吸引压特よび温度設定值の安定性から 0.6 $\sim 20.0 \mathrm{cP}$ とした．また測定結果は，1 回測定值扣よ び平均が 7 セグメント L E Dで表示, 拉よびシリアル プリンタに印字される。ささらに装置本体に GPIB を内 蔵しているため, 測定結果をパーソナルコンピュータ などに転送してデータ処理を行らことや，外部からり モートで装置の操作を行うことが可能である.

蒸留水および J I S 標準液 ( J I S 2.5, J I S 5, J I S 10, J I S 20)を温度 $20^{\circ} \mathrm{C}$ 没定して粘度 測定を行ったところ，標準偏差は最大でも䄪 $0.04 \mathrm{cP}$ と良好な結果が得られた。

本装置では各測定毎に細管の洗浄を自動的に行らた め, サンプル間の影響が防げるとともに, 連続したサ ンプル測定が可能となり, 省力化が有効に行兄ると思 われた.

\section{口2 ニードル型 CCD 顕微鏡の開発と心筋内微小血管の形態評価への応用}

立花博之, 矢田豊隆, 小笠原康夫, 平松 修, 木村昭洋, 山本徳則, 徳田周子, 辻岡克彦, 梶谷文彦 (川崎医大医用工学)

山森伸二, 大野浩平, 保坂栄弘 (日本光電工業)

〔目的〕心筋微小循環系は，血流調節の場であり， その評価は冠循環系の理解にとって極めて重要である. 特に心筋虚血が心内膜に多いことより, 心内膜微小循 環の解析は重要である.これまで生体䫓微鏡により心 筋表面の微小循環は観察されてきたが，心筋の動きを 㧕制した非生理的状態であることも，心内膜側での観 察ができないことなどに問題点があった，そこで本研 究では, 生理的条件下で心内外膜側微小血管の形態評 価を可能とするニードル型 C C D 顕微鏡を開発した。 〔装置の概要〕本装置は, 本体・カィラプローブよ りなり，プローブ先端にニードル（直径 $4.5 \mathrm{~mm}$, 長さ 180mm）を装着, ニードル内部には Gradient-Index Lens を組み込んでいる. 照射光は血管描出をより鮮 明にするため Green filter を通している. 被写体像 は対物レンズ $(\times 200)$ で抎大し CCD (1/2-inch interline transfer CCD image sensor, $510[\mathrm{H}] \times 429$
[V] pixels, 330-line holizontal resolution) 飞結像, T V 信号（標準 T Vフレーム数 30 フレーム/秒）への 変換を行 5. R G B 信号出打を備六高解像度VT R K 対応でき, コンピュータ画像解析により血管径等の形 態評価が可能である.

〔動物実験による検討】麻酔開胸豚を用い心内外膜 側の細動・静脈管径变化を心周期を通じて観察した。 ニードルは先端にドーナツ型バルーンを付けた she ath 内に内装し，血管を圧迫しないように注意深く血 管表面に近付けた. その結果, 心内外膜側微小血管を, 明瞭に観察できた。

[まとめ]本装置は生理的条件下での，心内外膜側 の微小血管の形態評価を心周期を通じて観察すること ができた. また，Green filterを用いることにより血 管イメージをより鮮明にすることができた。 